\title{
SOCAL CONSCIOUSNESS AND INDIFFERENT BUSINESS POSTURES
}

\author{
Dr. K. R. Subramanian ${ }^{1 *}$ \\ ${ }^{*}$ Visiting Professor \& Business Consultant
}

*Corresponding Author: -

\begin{abstract}
Synopsis: -
Businesses are created, sustained and expanded to gain more profit to the stake holders particularly the business owners. Social Responsibility of Business is talked about loudly, but there is lack of awareness of 'Social Consciousness'. At the grass root level business practices are in line with unscrupulous political and bureaucratic maneuvers to make a fast buck out of any situation of discomfort of people at large. Social consciousness of business is of recent origin and many American and foreign businesses are aware of the importance of this. India, which has contributed so much by Vedic and Upanishad literature to raise the level of consciousness has not lived up to raising consciousness of business to this level. The recent example is the 'Fire' accident at the Chennai silks building. An estimated one million Liters of water was consumed to control the fire at the cost of starving the parched city dwellers and depriving them of drinking water. When the whole city is reeling under shortage of drinking water is it not a moral responsibility of the owners of business to make some alternate arrangements or at least offer an apology? Where is the social consciousness gone? The subject matter of this article is the 'Social Consciousness'.
\end{abstract}

Keywords: - Social responsibilities of business, maneuvers of business, business postures contradicting their purpose, need for social consciousness.

\section{(c) $(\$)$}




\section{INTRODUCTION}

Businesses are created for the express purpose of social convenience and needs. But as the businesses get established and progress, they tend to forget the premise on which such businesses are established. A small social trigger will put them completely out of business. Analysis of different business failures will reveal this. As soon as the business loses its social focus and consciousness, it starts its decay and sooner this is understood the better for the business. This has been a common cause of decay of several prominent businesses. Such apathy to consumer concerns and a lack of sensibility to consumer aspirations and feelings can lead to business downfall. When businesses are doing well, it is the right time to put your feedback signals in place, so that you get an early warning when something is going wrong. The purpose of this article is t create an awareness among businesses to this sensitive area.

There have been a series of retail bankruptcies in 2017- as many as whole of 2016. J.C. Penney, RadioShack, Macy's, and Sears have each announced more than 100 store closures. Sports Authority has been liquidated, and Payless has filed for bankruptcy. Recently, several apparel companies' stocks hit new multi-year lows, including Urban Outfitters, and American eagle, and Ralph Lauren announced that it is closing its flagship Polo store on Fifth Avenue, one of several brands to abandon that iconic thoroughfare. A deep recession might explain an extinction-level event for large retailers. But GDP has been growing for eight straight years, gas prices are low, unemployment is under 5 percent, and the last 18 months have been quietly excellent years for wage growth, particularly for middle- and lower-income Americans. So, what the hell is going on? The reality is that overall retail spending continues to grow steadily, if a little meagerly. But several trends-including the rise of e-commerce, the over-supply of malls, and the surprising effects of a restaurant renaissance-have conspired to change the face of American shopping. How do we explain these business failures?

Here are three explanations for the recent demise of America's storefronts.

1. People are simply buying more stuff online than they used to.

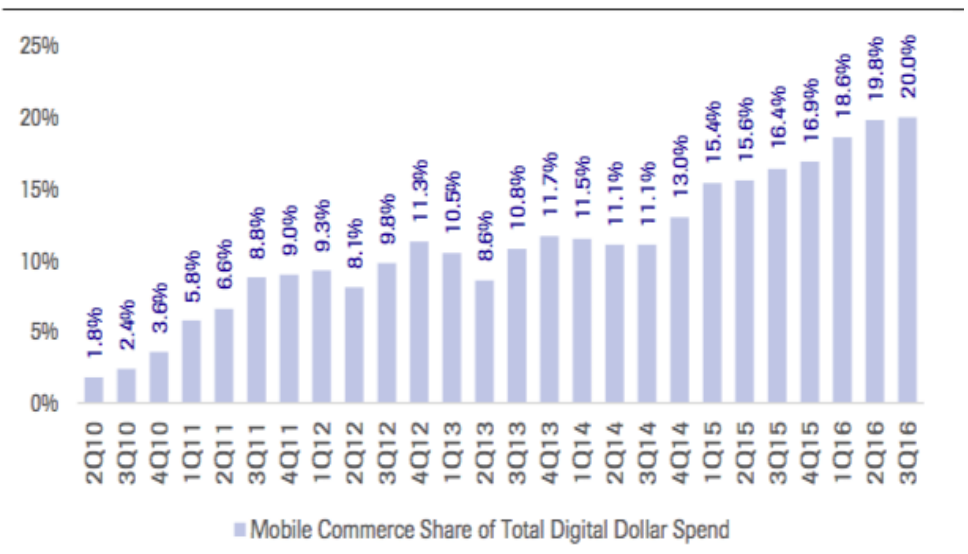

Figure 1: Digital platform growth in USA

2. It's no more surprise that the Great Recession created such a devastating blow: Mall visits declined 50 percent between 2010 and 2013, according to the real-estate research firm Cushman and Wakefield, and they've kept falling every year since.

3. Americans are shifting their spending from materialism to meals out with friends. There is no question that the most significant trend affecting brick- and-mortar stores is the relentless march of Amazon and other online retail companies. But the recent meltdown for retail brands is equally about the legacy of the Great Recession, which punished logo-driven brands, put a premium on experiences (particularly those that translate into social media moments), and unleashed a surprising golden age for restaurants.

What we see today in the USA is perhaps the scenario in India in the not-so-distant future as the Consumer preferences change.

\section{Objectives and Methodology}

Businesses have been created and sustained because they serve a social cause. But the same businesses if they fail to serve the social objectives for which they were created in the first place may lose out. What the businesses lack is a 'Social Consciousness'. This article hopes to bring out the social Consciousness and responsibility of business to Focus. The broad objectives of this research paper are:

1. Identification of social objectives for business.

2. To analyze how businesses have fared with 'Social Consciousness'.

3. Environmental factors affecting Social consciousness of businesses

4. Changes in business environment affecting Social consciousness of business.

5. Social Consciousness of Business - Does it need a redefinition?

6. Conclusions and recommendations 
The subject matter is very much current and discussed in all forums. Due to changes in business outlook and the impact of media on society and culture, businesses need to redefine their purposes in the light of the new generational aspirations and expectations!

\section{Review of Literature}

The term conscious business implies that a business will seek to be conscious of its impact on the world in various spheres, and continue this inquiry over time. It is concerned with both its impact on a human's inner and outer world as well as animal and environmental well-being. Furthermore, a conscious business considers both short-term and longterm effects of its actions or inactions on the environment. A conscious business evolves as does the methods that a business can and chooses to be of benefit to the world and to function with awareness. Therefore, though conscious businesses will be socially responsible, the term "conscious business" holds larger connotations for the businesses' actions than social responsibility. The Conscious Business movement in the US, which emerged from the theory of corporate social responsibility, pushes for "values-based" economic values where values represent social and environmental concerns at both global and local scales. This effort is related to not-just-for-profit business models, conscious consumerism, and socially responsible investing. Though this is of recent origin in USA, the awareness of Consciousness has been in India for centuries, as propounded in the Vedic literature and history.

On a broad scale, how do we create altruistic organizations that can really transform society and transform economic systems? We need a new generation of leaders to step forward and provide this new kind of leadership. The basic premise is that compassionate, authentic leadership is essential. It's not just that it's good to have-it's necessary for a healthy society. As a result of the failures of leadership in the last decade, there's been a loss of confidence in our leaders, and a loss of trust. The role of the leader

in this century is different than in centuries past. It's to bring people together around this sense of meaning, purpose, and values. It is a very difficult task, particularly in organizations that span the globe, to gain that kind of alignment where people believe in the purpose of the organization and practice its values. Empowerment of people leads to better social conscious leadership.

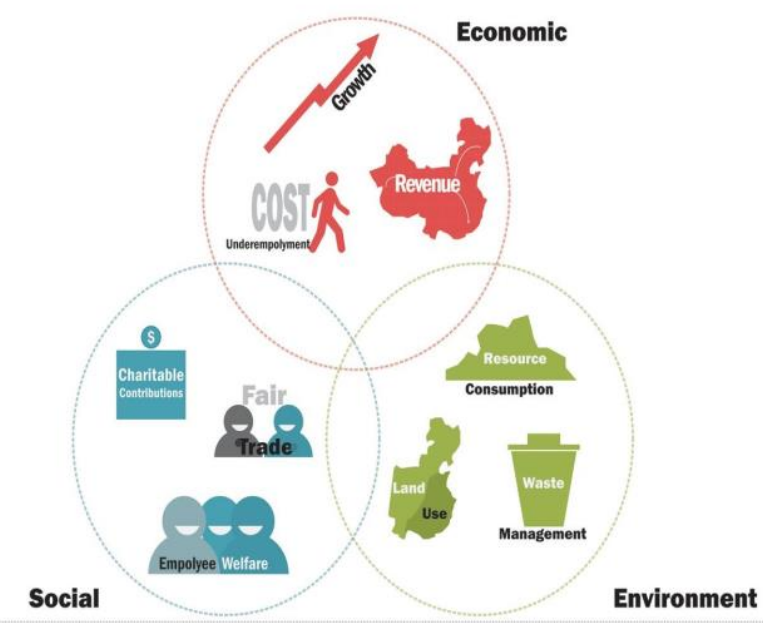

Figure 2: Elements of Social Consciousness

William George is a professor of management practice at Harvard Business School, where he teaches leadership development and ethics. He is the former chairman and CEO of Medtronic. To quote George "Let me give you an example of a woman whom I met at Medtronic many years ago. She was making heart valves. If a human heart valve failed, they could actually take a valve from the pig and use it to replace the failed human heart valve. This woman was the top worker in the plant. When I asked her about her work, she looked at me with passion in her eyes and said, "My job is to make heart valves the save people's lives. I make one thousand heart valves a year. If one valve is defective, someone will die, and I could never live with the idea that I caused the death of another person." But she also said, "You know, when I go home at night, what I'm thinking about is that there are five thousand people in the world today who are alive and healthy because of the products I made.'This woman is an empowered leader. She doesn't have a formal leadership role, and she isn't a supervisor, but everyone looks to her for inspiration. This is the kind of empowered leadership we need to spread more broadly.

Socially conscious business models have garnered a lot of attention lately. This is evident just by walking through the doors of the Center for Social Entrepreneurship in New York City, an entire co-working space, community, and launch pad built specifically for entrepreneurs starting socially conscious businesses. However, this shift toward social entrepreneurship isn't limited to startups and small brands. Even large, well-established companies like Patagoniawhich was founded on a three-pronged mission "to build the best products, do no unnecessary harm and to use business to inspire solutions to the environmental crisis" - have made socially conscious business practices the platform of their organizations. Even companies that have long been considered "traditional," (translation: stuck in their ways) have been 
taking broad strokes to become more socially conscious. Daily Finance cites Wal-Mart, Waste Management and Unilever as three of five surprising companies that have gone green - the final focused entirely on "altering its business model with a focus on sustainability." Socially conscious business practices are no longer just a "perk" or selling point for PR purposes. Both from a business and profitability standpoint, and from a moral standpoint, being socially conscious should be a requirement. Department stores have failed as anchors, but better food, entertainment, and even fitness options might bring teens and families back to struggling malls, where they might wander into brick-and-mortar stores that are currently at risk of closing.

Today, when corporations can be more influential than entire states, where we put our money is where the power lies. The problem is the world of business can be opaque and supply chains are murky, so it is difficult to confidently make an informed choice. The retail manufacturing industry is the second most polluting industry on earth, second only to oil. According to Annie Leonard, an expert in overconsumption, only 1\% of the materials used to produce our consumer goods are still in use six months after sale. Somewhere, the value of craftsmanship and of provenance has been lost. Price and speed are trumping value. Increasing awareness around these issues has led to a rise in what is known as conscious consumption, a movement of people who seek out ways to make positive decisions about what to buy and look for a solution to the negative impact consumerism is having on our world.

According to the Network for Business Sustainability's systematic review of 91 studies. The average premium consumers will pay is about $10 \%$. This primer defines and describes the factors that determine that premium. Socially conscious consumerism can be defined as consumers purchasing products and services produced responsibly. Responsible production can encompass a range of social and environmental factors, such as ensuring labor practices are fair or that products are produced with the aim of minimizing environmental impacts. Consumers reward socially responsible firms through higher sales and punish other firms through boycotts and protests. Many researchers and managers believe corporate social responsibility rests with consumers. From their perspective, as long as consumers demand responsible products, companies will deliver them. While issues regarding and concerns of conscious consumerism are appreciated, it is still a moot question if consumers are able to analyze each and every one of their purchases by evaluating the producers for their social consciousness!

A recent survey of more than 2,000 adults revealed that nearly 90 percent of them described themselves as conscious consumers (i.e. they were more likely to by products produced in socially and environmentally responsible ways) and the number of socially minded consumers is increasing. As more and more consumers identify themselves as Conscious consumers, the need to understand who they are and what drives them becomes more important to business. But, there is no one socially conscious consumer. There is no demographic (age, gender, income, education, country) or psychographic (attitudes, lifestyle, morals) profile. Also, research shows that self-described — conscious\| consumers may intend to purchase responsibly but fail to do so at the point of purchase. This attitude-behavior gap leaves companies wondering whether consumers are actually ready to back up their intentions with their purchasing dollars.

\section{A Model of Socially Conscious Consumerism}

A Firms' CSR actions influence consumers' attitudes. Consumers' attitudes shape their intentions, and their intentions affect their behavior. So, firms' CSR actions may inspire consumers to change their purchasing behavior (i.e. buy a different product), pay a premium for responsible products, or even deliberately punish those firms that fail to meet their expectations. The figure 3 given below indicates a design approach model for social consciousness in business attitudes. For example how a product can be marketed by a socially conscious business in indicated below:

Don't market to a single socially conscious consumer. Avoid chasing the - conscious consumer\| as if there is only one kind. Figure out which issues and product features are important to your various customer segments and market to them accordingly. Explain how consumers will make a difference. One study found consumers' belief that they could make a difference to the environment was more important in determining purchasing than their actual concern for the environment. Communicate how each consumer's purchase contributes to the broader social goal. Maintain product quality and functionality. Consumers are unwilling to compromise product quality or features for social consciousness. Communicate carefully. Companies need to strike a delicate balance between legitimately informing consumers of positive sustainability actions and not over-emphasizing modest claims.

Despite the research conducted to date, we still don't have all the answers. There is a rich body of research growing in consumer psychology, influence, and communication that seeks to provide more guidance on these issues. A range of social motivations such as altruism, reciprocity, and signaling is likely at work. Future research should examine not just why consumers buy but also why they boycott, spread negative word of mouth, and protest. Consumers consistently say they care about companies' social performance, but often these words do not translate into actions. The evidence so far suggests consumers are influenced by such simple factors as the placement of the responsibility message and other information they have about the firm. By over promoting, firms expose themselves to scrutiny if a social or environmental issue arises. More information is now available through third party sources to consumers motivated enough to seek it out. They are influenced by such simple factors as the placement of the responsibility message and other information they have about the firm. By over promoting, firms expose themselves to scrutiny if a social or environmental issue arises. More information is now available through third party sources to consumers motivated enough to seek it out. 


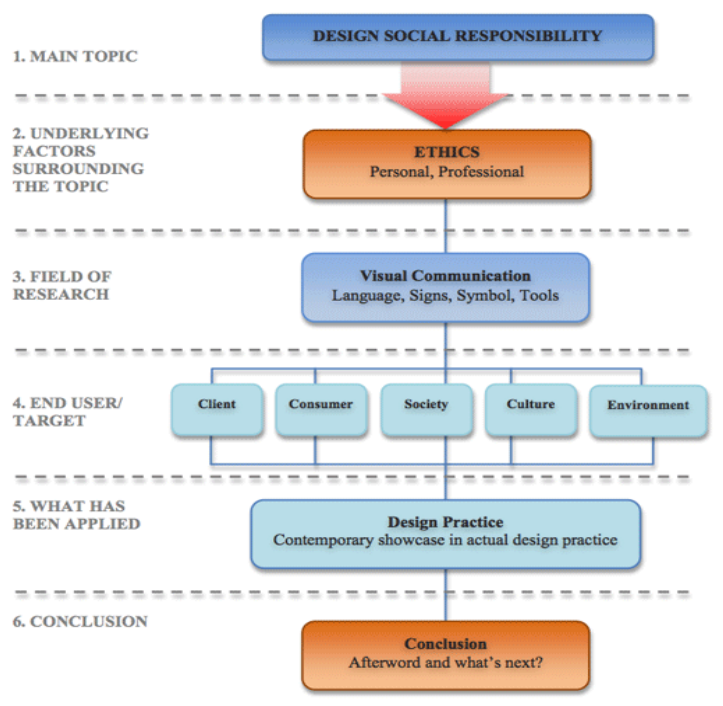

Figure 3: CSR and Social Consciousness - a design approach

The purpose of promotion and all marketing activities is to build a lasting relationship with your consumer.

\section{Factors That Enhance Relationship}

- Consumer knowledge of positive company actions

- A positive attitude towards the firm

- A good fit between the company or brand and its CSR initiatives

- The belief that their purchase will make a difference

- Consumer's perception of themselves and perception of the business as acting responsibly

- Product seen as consistent with brand

- Product aligns with an issue important to the consumer

- Simple claims and labeling on the product

- Effective in-store education of consumer about the product

- Purchase requires only a small commitment by consumer

\section{Factors That Impede}

- Consumer knowledge of negative company actions

- A negative attitude towards the firm

- Seemingly contradictory actions by the firm

- Perceived lower quality of responsible product

- Belief that their responsible purchase won't make a difference

- Consumer confusion at point-of-purchase around the product's responsible attributes

- Misleading or confusing packaging

- Competition between brands

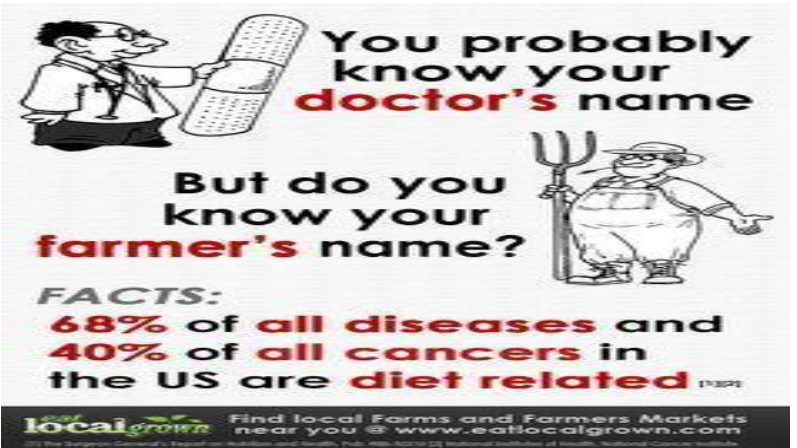

Figure 4: Illustrates that we still do not have all the figures.

The point is, as business owners we all need to make a commitment to making socially conscious practices a part of their business, in the same way we make accounting, marketing, or human resources a part of our businesses. Whether it is using solar and wind power to run manufacturing; sourcing our products from vendors who respect the earth, people and animals; or providing our employees with the benefits they need to live well at and away from work, we need to commit to making these changes and be completely transparent in doing so. For those business owners who aren't 
easily scared, or don't think they have the infrastructure to support such a shift, perhaps it's more impactful to talk about the benefits of social responsibility to the business itself. In addition to just being the right thing to do, socially conscious practices are also profitable.The correlation between social entrepreneurship and corporate sustainability. Sustainability - closely linked to profitability - is one of the tenants of social entrepreneurship. And there are plenty of companies that started out small and have accomplished just that. Look where they are now, in most cases beating out those who are slow to change.

Many of us are unknowingly supporting the perpetuation of modern-day slavery through our daily consumer habits, just by purchasing from companies who haven't fully vetted the practices of their supply chains. So much so, that the interactive website Made in a Free World was founded to allow anyone to compile information about their consumer habits and estimate the correlation of those habits to the promotion of slavery. There are organizations currently building a revolutionary tool for companies to directly address slavery in their supply chains, along with a movement to partner with companies who are actively building "a free world," by practicing socially conscious business.

As far as appearances are concerned, from corporate to cultural measures and everything in between, we live in a world that cares about social entrepreneurship and corporate sustainability. It's time we start consistently acting on that feeling.

\section{Data Analysis and Inferences}

One of the mistakes people make when thinking about the future is to think that they are watching the final act of the play. Mobile shopping might be the most transformative force in retail-today. But self-driving cars could change retail as much as smart phones. Once autonomous vehicles are cheap, safe, and plentiful, retail and logistics companies could buy up millions, seeing that cars can be stores and streets are the ultimate real estate. In fact, self-driving cars could make shopping space nearly obsolete in some areas. CVS could have hundreds of self-driving minivans stocked with merchandise roving the suburbs all day and night, ready to be summoned to somebody's home by Smartphone. A new luxury-watch brand in 2025 with its autonomous showroom vehicle could circle the neighborhood, waiting to be summoned to the doorstep of a tony apartment building. Autonomous retail will create new conveniences and traffic headaches, require new regulations, and inspire new business strategies that could take even more businesses out of commercial real estate. The future of retail could be even weirder yet.

Consumer consciousness has been aroused and there is no escape route for business other than satisfy the consumer needs and expectations in this regard. They are very sensitive about the process, the procurement and distribution of goods and services in socially acceptable ways so that the brand is sold!

\section{Conclusions And Recommendations}

Every business identifies itself in society by socially relevant objectives and how their operations would benefit the society. For example, a new Automobile plant located in a new city gives employment opportunities and creates further business opportunities for down the line industries, Dealerships, technical training of suitable candidates form the locality for good employment opportunities for youngsters etc. It creates opportunities for new educational and training institutions and also for retail outlets and Big Departmental stores to be located. This helps in the overall development of the area. Business needs to maintain its focus and orientation to social consciousness to be successful in the current environment.

Social consciousness of businesses has shown a remarkable improvement in the last few years with several industries coming forward to work with local entrepreneurs for socially relevant efforts of the community. The Commitment of industries to greenhouse effects and emission controls are remarkable. Consumer attitudes are determined by social commitment of companies, and by and large, companies have been successful in identifying sensitive areas and taking corrective actions in their outlook. Social entrepreneurship is an outgrowth of socially responsible businesses. Enlightened business organizations have demonstrated their commitment to social consciousness, through their purchasing, producing and selling policies.

Business environment has a profound impact on how a business is organized and conducted. Labor laws have become more stringent and made companies realize their consciousness. Pollution control has become more stringent and norms for establishment of new ventures have become environment friendly. There has been a general appreciation of environmental impact of all activities and so businesses have taken good care of the same. Even in recruitment there is better awareness as it might become difficult to hire potentially good candidates without an organizational commitment to social consciousness. From recruitment to manufacturing practices to selling and advertising, organizations have become more aware of their social responsibilities and so their social consciousness has improved.

Digital transformation of businesses is the latest development in all sectors. Social media is powerful and is already exerting its influence through fast communications. It does not take much time for prospective customers to get to know of a bad product or even a small slip up in customer service! Businesses have to respond very fast and convincingly to customer complaints and take positive actions immediately to keep up their image. Truly, the customer has been empowered in the digital age. 
There is no need to redefine the customer consciousness as organizations are reminded through their own social networks and information systems. Well, one thing for sure, organizations have to be on their toes to match the customer expectations today. One recommendation for the $21^{\mathrm{st}}$ century organizations would be to take the initiative and identify areas for improvement on a continuous basis before a problem gets highlighted. Lack of social consciousness and sensitivity to social problems and issues will lead to business decay.

\section{References}

[1].Abergene, Patricia; Megatrends 2010: The Rise of Conscious Capitalism.

[2].Hampton Roads

[3].Publishing Company (September 2005).

[4].Burden, P and Warwick R; Leading Mindfully. Burden and Warwick (2015)

[5].Dalai Lama and Cutler, H; the Art of Happiness at Work. Holder and Stoughton (2003)

[6].Hague, USAir; Bitterness: Economics for Humans. Harvard Business Review Press (December 19, 2011)

[7].Hawke, Paul; Natural Capitalism. Back Bay Books; 1st edition (October 12, 2000).

[8].Kaufman, Fred; Conscious Business: How to Build Value through Your Values.

[9].Sounds True: September (2006).

[10]. Mackey, John; Sismondi, Rajendra; Conscious Capitalism: Liberating the Heroic Spirit of Business. Harvard Business Press (January 2013)

[11]. McInnes, Will; Culture Shock. John Wiley \& Sons (2012)

[12]. Price, John; The Conscious Investor. John Wiley \& Sons (2011)

[13]. Renesch, John; Conscious Leadership. Brown \& Herron (June 17, 2002)

[14]. Sisodia, Rajendra; Wolfe, David; Sheth, Jagdish; Firms of Endearment: How World-class Companies Profit from Passion and Purpose. Pearson Prentice Hall (February 10, 2007)

[15]. Caring Economics: Conversations on Altruism and Compassion, Between Scientists, Economists, and the Dalai Lama by Tania Singer and Matthieu Ricard. Published in April 2015 by Picador USA. All rights reserved.

[16]. Roberts, James A. (1996). Green Consumers in the 1990s: Profile and Implications for Advertising. , Journal of Business Research, 36, 217-231.

[17]. Ajzen I., Fishbein M. (1980). Understanding attitudes and predicting social behavior. Englewood Cliffs, NJ: Prentice Hall. Google Scholar

[18]. Bagozzi R. P., Gopinath M., Nyer P. U. (1999). The role of emotions in marketing. Journal of the Academy of Marketing Science, 27, 184-206.

[19]. Becker-Olsen K. L., Cudmore B. A., Hill R. P. (2006). The impact of perceived corporate social responsibility on consumer behavior. Journal of Business Research, 59, 46-53.

[20]. Bigné E., Currás-Pérez R., Aldás-Manzano J. (2012). Dual nature of cause-brand fit: Influence on corporate social responsibility consumer perception. European Journal of Marketing, 46, 575-594

[21]. Illia L., Zyglidopoulos S. C., Romenti S., Rodríguez-Cánovas B., Del Valle Brena G. (2013). Communicating corporate social responsibility to a cynical public. MIT Sloan Management Review, 54(3), 16-19

[22]. Kotler P., Lee N. (2005). Corporate social responsibility: Doing the most good for your company and your cause. Hoboken, NJ: John Wiley

[23]. Lauritsen B. D., Perks K. J. (2015). The influence of interactive, non-interactive, implicit and explicit CSR communication on young adults' perception of UK supermarkets' corporate brand image and reputation. Corporate Communications, 20, 178-195.

[24]. Lichtenstein D. R., Drumwright M. E., Braig B. M. (2004). The effect of corporate social responsibility on customer donations to corporate-supported nonprofits. Journal of Marketing, 68(4), 16-32

[25]. Lii Y. S., Lee M. (2012). Doing right leads to doing well: When the type of CSR and reputation interact to affect consumer evaluations of the firm. Journal of Business Ethics, 105, 69-81.

[26]. Newhagen J. E. (1998). TV news images that induce anger, fear, and disgust: Effects on approach-avoidance and memory. Journal of Broadcasting \& Electronic Media, 42, 265-276.

[27]. Kofman, Fred (2006). Conscious Business: How to Build Value through Values. Boulder: Sounds True.

[28]. Howes, Lewis. "5 Secrets to Building a Business -- With Heart". Entrepreneur Magazine. Retrieved 17 April 2015.

[29]. Pete Burden and Rob Warwick: The Purpose and Practice of Conscious Business AMED, Spring 2014

\section{Web References}

[1].www.corporatecritic.org,

[2].www.corpwatch.org

[3].www.bbmg.com

[4].https://www.theguardian.com/business/2015/mar/21/starbucks-face-conscious- capitalism

[5].http://www.usatoday.com/story/money/business/2013/03/25/kindness-panera- bread-nordstrom-starbucks/1965183/

[6].www.twitter.com/richard_maize 